\title{
Mekanisasi Produksi untuk Peningkatan Kualitas dan Standardisasi Produk UMKM LeBon Tangerang
}

\author{
Muhammad Setiawan Kusmulyono \\ Universitas Prasetiya Mulya, Tangerang, Indonesia
}

Corresponding author: Muhammad Setiawan Kusmulyono, setiawan@pmbs.ac.id

\begin{abstract}
Abstrak: UMKM Tradisional merupakan usaha yang dirintis dengan model bisnis tradisional yang masih mengandalkan pendekatan manual dalam berbagai proses bisnis yang dijalankan. Hal ini sangat wajar mengingat pengetahuan dan keterampilan pengusaha mikro, kecil, dan menengah sangat terbatas dan lebih banyak fokus pada pengelolaan kegiatan produksi. Dampaknya, efisiensi dan efektivitas produksi serta daya saing menjadi rentan terhadap kompetisi yang ada di pasar. Bagi UMKM tradisional yang tidak mampu menjaga kualitas dan standardisasi produk, usaha mereka pasti akan menghadapi masalah yang semakin beragam. Sayangnya, upaya yang dilakukan untuk membantu UMKM ini terkendala banyak masalah. Banyak pendamping UMKM seringkali memberikan pemahaman dengan konsep yang rumit dan tidak sesuai dengan kebutuhan para pengusaha. Hal ini membuat makna pendampingan tidak tersampaikan dengan baik. Oleh karena itu, penelitian tindakan yang merupakan bagian dari kegiatan pengabdian masyarakat ini berupaya untuk mengidentifikasi peran mekanisasi dalam proses produksi yang dilakukan oleh Usaha LeBon, sebuah bisnis yang mengolah sumber daya ikan menjadi makanan cepat saji. Masalah kapasitas dan standardisasi produksi menjadi masalah yang menghambat kinerja perusahaan. Dengan bantuan pendanaan program hibah DIKTI, pembelian mesin dan pengaturan sistem produksi ternyata mampu mendorong kinerja usaha LeBon lebih efisien. Hal ini menunjukkan bahwa proses pendampingan usaha mikro tidak harus selalu menghadirkan kerumitan dan kompleksitas melainkan pentingnya identifikasi awal untuk menemukan akar masalah dan kemudian menghasilkan solusi yang tepat guna.
\end{abstract}

Kata Kunci: mekanisasi, sederhana, efisiensi produksi, kapasitas, standardisasi

Abstract: Traditional MSMEs are businesses initiated by traditional business models that still rely on manual approaches in various business processes being conducted. This is very reasonable considering the knowledge and skills of micro, small and medium entrepreneurs are very limited and focus more on the management of production activities. As a result, production efficiency and effectiveness as well as competitiveness are vulnerable to existing competition in the market. For traditional MSMEs that are unable to maintain product quality and standardization, their businesses will inevitably face increasingly diverse problems. Unfortunately, the efforts made to help MSMEs are plagued by many problems. Many MSME facilitators often provide understanding with complex concepts that do not suit the needs of entrepreneurs. This action research which is part of community service activities seeks to identify the role of mechanization in the production process carried out by LeBon SME, a business that processes fish resources into fast food. The problem of capacity and standardization of production is a problem that impedes company performance. With the help of the DIKTI grant program funding, the purchase of machinery and production system settings

Submitted: 12.4.2020, Revised: 27.10.2020, Accepted: 28.10 .2020 
turned out to be able to drive the business performance of LeBon more efficiently. This shows that the micro business assistance process does not always have to present complexity and complexity but rather the importance of early identification to find the root of the problem and then produce an appropriate solution.

Keywords: mechanization, moderate, production efficiency, capacity, standardization

\section{Pendahuluan}

Salah satu ciri seorang wirausaha adalah kemampuannya dalam melihat suatu fenomena masalah, yaitu ketika orang lain melihatnya sebagai masalah, maka wirausaha tersebut dapat mengidentifikasi fenomena tersebut sebagai peluang (Kusmulyono, 2016; Siegel \& Renko, 2012; Venkataraman, 2000). Kondisi LeBon, sebuah merek dagang sederhana yang menjual olahan hasil ikan lele, milik Bapak Riyan, pengusaha mikro dari Desa Dangdang, Kecamatan Cisauk, Kabupaten Tangerang, juga menerapkan hal yang sama. Bapak Riyan sebagai pemilik LeBon mampu melihat potensi dan peluang dari kondisi masalah yang ada.

Dalam pandangan Bapak Riyan dan LeBon, popularitas lele menurun karena dianggap hidup di lingkungan yang tidak bersih. Ikan Lele dianggap sebagai ikan yang mengkonsumsi makanan yang tidak higienis, walaupun dari sisi kandungan nutrisi merupakan salah satu ikan dengan nutrisi yang beragam dan bermanfaat bagi kesehatan tubuh. Namun, Bapak Riyan tidak menyerah dalam menghadapi persepsi miring akan ikan Lele. Melalui LeBon, lele dapat diolah menjadi produk bernilai tambah yang menyehatkan. Produk-produk yang dimiliki oleh LeBon antara lain bakso ikan lele, risol lele, dan makanan olahan lele berbasis terigu.

Bapak Riyan dan LeBon merupakan mitra dari program pengabdian masyarakat yang dirintis berdasarkan perolehan hibah PKM Dikti. Beliau memiliki semangat yang tinggi dan kreativitas yang luar biasa dalam mengolah ikan lele menjadi berbagai produk turunan yang menarik. Sayangnya, proses produksi yang masih tradisional dan aktivitas yang masih manual tidak mampu menunjang semangat Bapak Riyan untuk dapat mengoptimalkan mimpi yang dimiliki. Akibat dari manualnya produksi, produktivitas menjadi lebih rendah sehingga walaupun produk memiliki order yang berlimpah, hal itu akan selalu sulit dipenuhi mengingat proses yang masih manual.

Bapak Riyan menjalankan usaha ini bersama istrinya dengan sistem yang masih tradisional, baik dari sistem produksi maupun sistem lainnya. Bapak Riyan tidak memiliki pekerja tetap, namun kadang mempekerjakan tetangganya jika ada pesanan yang berjumlah besar. Saat ini, Bapak Riyan tidak memiliki titik penjualan yang tetap. Strategi berjualan masih mengandalkan pesanan dari orang-orang yang telah mengenal produk Bapak Riyan dan juga dengan mengikuti Bazaar.

Sebagai usaha yang masih tradisional, tantangan yang dihadapi Bapak Riyan pun sangat beragam, mulai dari standardisasi kualitas produk, kapasitas produksi, hingga manajemen waktu produksi. Tidak jarang, masalah dalam produksi ini berimbas langsung terhadap keuntungan yang akan diperoleh Pak Riyan. Misalnya saja dengan pesanan yang banyak, hampir seluruh kegiatan produksi dilakukan dengan manual dan teknologi yang sederhana. Imbasnya, pesanan tidak dapat terpenuhi dan akhirnya pendapatan pun tidak dapat diperoleh optimal.

Kapasitas produksi adalah masalah pertama yang dihadapi oleh Bapak Riyan dan usaha LeBon yang dijalaninya. Salah satu kunci dalam proses produksi bakso ikan lele adalah pembuatan adonan yang kalis. Sayangnya, Bapak Riyan hanya mengandalkan sebuah mesin mixer kue yang hanya mampu membuat adonan 150 gram per proses. Padahal, jika Bapak 
Riyan memperoleh pesanan banyak, adonan yang dipersiapkan dapat mencapai 2 - 3 kilogram. Selain itu, mixer kue tersebut membutuhkan waktu sekitar 40 - 50 menit untuk membuat adonan menjadi kalis. Dalam proses mengaduknya pun, setiap 30 detik, Bapak Riyan harus memberikan jeda bagi mesin mixernya. Imbasnya, untuk membuat 1 adonan kalis, membutuhkan waktu sekitar 1 jam. Jadi, jika ingin membuat pesanan bakso dengan adonan 2 kilogram, butuh lebih dari 15 jam hanya untuk membuat adonannya saja.

Masalah kedua yang dihadapi oleh Bapak Riyan adalah standardisasi kualitas. Standardisasi kualitas adalah upaya usaha agar dalam setiap produk yang dibuat selalu sama di setiap waktunya. Dalam usaha bakso Bapak Riyan ini, pembuatan bulatan bakso masih menggunakan tangan kosong, sehingga setiap bakso yang dihasilkan menjadi tidak standar. Walaupun dari sisi pembumbuan sudah optimal, namun bentuk yang tidak standar dapat membuat citarasa produk menurun sangat ingin disantap.

Masalah ketiga yang dihadapi berikutnya adalah mengenai penyusutan bahan baku utama. Penyusutan ini merupakan suatu hal yang alamiah. Hal ini dikarenakan dalam proses produksi lele olahan, Bapak Riyan hanya ingin mempergunakan daging terbaik, sehingga bagian-bagain ikan lele yang tidak dipergunakan akan dibuang. Oleh karena itu, penyusutan dapat mencapai $70 \%$. Jadi, dari sekitar 1 kilogram lele hidup, daging ikan yang dapat diolah hanya sekitar 300 gram saja.

Oleh karena itu, pembahasan dalam artikel ini akan mengidentifikasi bagaimana kegiatan pengabdian masyarakat yang dilakukan di usaha LeBon milik Bapak Riyan ini mampu membantu mengidentifikasi dan mengatasi masalah produksi yang dihadapi LeBon untuk menunjang kinerja bidang pemasaran.

Faktor penting dalam merintis sebuah usaha adalah adanya peluang (Chang, W.L., Liu, W.G.H., dan Chiang, 2014; Hsieh et al., 2009; Laage-hellman et al., 2018; Venkataraman, 2000). Di dalam objek LeBon, mitra telah mampu mengidentifikasi peluang, namun belum optimal. Oleh karena itu, langkah pertama dalam pelaksanaan PKM ini, adalah melakukan identifikasi terhadap kondisi awal usaha dari LeBon untuk meninjau keseluruhan proses bisnis di dalamnya, mulai dari manajemen usaha, aktivitas produksi, dan pemasaran. Hal ini sejalan dengan penelitian yang dilakukan oleh Kusmulyono (2016) bahwa kemampuan identifikasi peluang merupakan salah satu hal yang penting untuk mewujudkan kinerja usaha yang optimal.

Luaran dari tahap identifikasi ini adalah tersedianya rencana aksi yang akan disusun untuk menyelesaikan masalah yang ditemukan dalam proses audit. Hal ini penting karena peluang usaha untuk berkembang sering terabaikan dan seorang wirausaha harus mampu untuk mendayagunakan pikirannya dalam menganalisis kondisi lingkungan luar (Chang, W.L., Liu, W.G.H., dan Chiang, 2014)

Langkah pertama yang dilakukan dalam bidang manajemen usaha adalah merumuskan ulang nilai tambah produk, visi, misi, tujuan, dan sasaran usaha. Hal ini merupakan langkah awal sebelum merumuskan strategi bersaing perusahaan. Strategi bersaing merupakan suatu prasyarat bagi sebuah organisasi untuk mulai menentukan atribut yang digunakan untuk melampaui pesaingnya (Ehrenhard et al., 2017; Porter, 1990). Luaran dari aktivitas di bidang manajemen usaha ini adalah tersedianya strategi bersaing dan strategi di tiap fungsional usaha, terutama dalam pemasaran dan produksi.

Sesuai dengan prioritas permasalahan yang telah dirumuskan di bagian awal penelitian ini, maka produksi menjadi prioritas pertama sebelum pemasaran. Hal ini dilakukan karena LeBon masih terkendala dengan produksi yang bersifat manual. Jika tidak segera dientaskan, maka berapapun permintaan pasar yang diterima, tidak akan pernah dapat dipenuhi. Hal ini sesuai dengan penelitian yang dilakukan oleh Rahman \& Ramos (2010) yang menunjukkan bahwa secara umum, usaha kecil dan menengah mengalami masalah karena kurangnya 
keterampilan dalam hal manajerial dan teknis untuk mendukung efektivitas usahanya. Oleh karena itu, di bagian produksi ini akan difokuskan untuk melakukan mekanisasi beberapa bagian proses produksi untuk mempercepat proses produksi agar lebih efektif dan efisien. Mekanisasi ini diawali dengan identifikasi kebutuhan mesin, lalu survei mesin yang diinginkan dan kemudian pemasangan dan ujicoba.

\section{Metodologi}

Kegiatan pengabdian kepada masyarakat di usaha LeBon milik Bapak Riyan ini dilakukan dengan metode penelitian tindakan (action research). Peneliti yang juga melakukan kegiatan pengabdian turut andil dalam mengidentifikasi masalah dan kemudian merumuskan masalah bersama mitra (Abrahamsen et al., 2016). Tidak hanya itu, peneliti bersama mitra juga menyusun kerangka solusi bersama untuk kemudian diwujudkan dalam mengatasi masalah produksi yang dialami oleh mitra.

Desain penelitian yang dilakukan menggunakan pendekatan kualitatif dimana metode observasi dan wawancara menjadi sumber utama dalam pengumpulan data. Observasi yang dilakukan meliputi kegiatan produksi dan pemasaran yang dilakukan oleh mitra. Penelitian ini juga mengidentifikasi dokumen yang dimiliki oleh mitra, yaitu dokumen keuangan dan produksi. Analisis data yang akan dilakukan adalah analisis terhadap hasil produksi dengan menggunakan pendekatan baru.

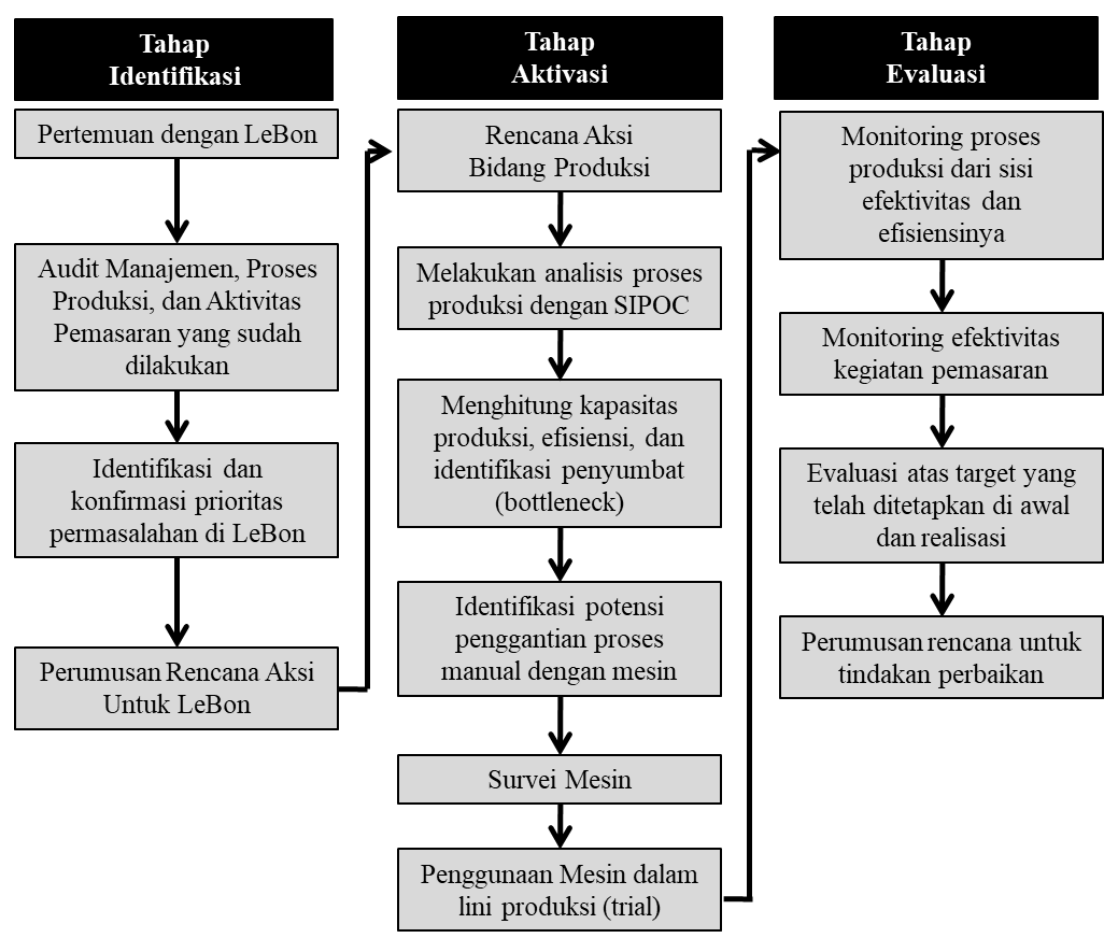

Gambar 1. Alur Proses Pelaksanaan Penelitian Tindakan

\section{Hasil dan Pembahasan}

Bapak Eko Supriyanto akrab dikenal dengan nama Bapak Riyan. Beliau memiliki usaha olahan produk dari ikan lele. Beliau memiliki merek LeBon yang merupakan kependekan dari lezat, bergizi, dan original. Beliau telah menjalankan usaha ini sejak tahun 2015. Produk olahan 
lele yang mampu dihasilkan Bapak Riyan antara lain bakso lele (baik beku maupun siap saji), risoles lele (beku maupun siap saji), dimsum lele, abon lele, dan keripik lele.

Nilai tambah utama dari produk Lebon ini tentunya adalah memiliki gizi yang tinggi karena protein ikan lele. Kemudian, beberapa produk olahan ditawarkan dalam tampilan yang menarik, yaitu warna-warni, seperti bakso lele warna warni. Warna-warni yang ditawarkan adalah warna merah yang berasal dari buah naga, warna hijau dari daun kelor, dan warna kuning dari wortel.

\section{A. Hasil}

Sebagai data awal, sebelumnya, Bapak Riyan hanya mengandalkan sebuah mesin mixer kue yang hanya mampu membuat adonan 150 gram per proses. Padahal, jika Bapak Riyan memperoleh pesanan banyak, adonan yang dipersiapkan dapat mencapai 2 - 3 kilogram. Selain itu, mixer kue tersebut membutuhkan waktu sekitar 40 - 50 menit untuk membuat adonan menjadi kalis. Dalam proses mengaduknya pun, setiap 30 detik, Bapak Riyan harus memberikan jeda bagi mesin mixernya. Imbasnya, untuk membuat 1 adonan kalis, membutuhkan waktu sekitar 1 jam. Jadi, jika ingin membuat pesanan bakso dengan adonan 2 kilogram, butuh lebih dari 15 jam hanya untuk membuat adonannya saja.

Berdasarkan analisis masalah dan kesepakatan bersama, maka peneliti mengajukan pembelian mesin produksi antara lain:

- Mesin adonan tepung 20 Liter dengan harga Rp 6.990.000

- Mesin adonan bakso AST-ABX22 dengan harga Rp 3.990.000

- Mesin vacuum packaging AST-DZ-300T dengan harga Rp 8.990.000

- Mesin cooler dengan harga Rp 3.800.000

- Mesin expired date dengan harga Rp 990.000

- Biaya menaikkan tegangan listrik rumah Bapak Riyan sebesar Rp 2.205.937
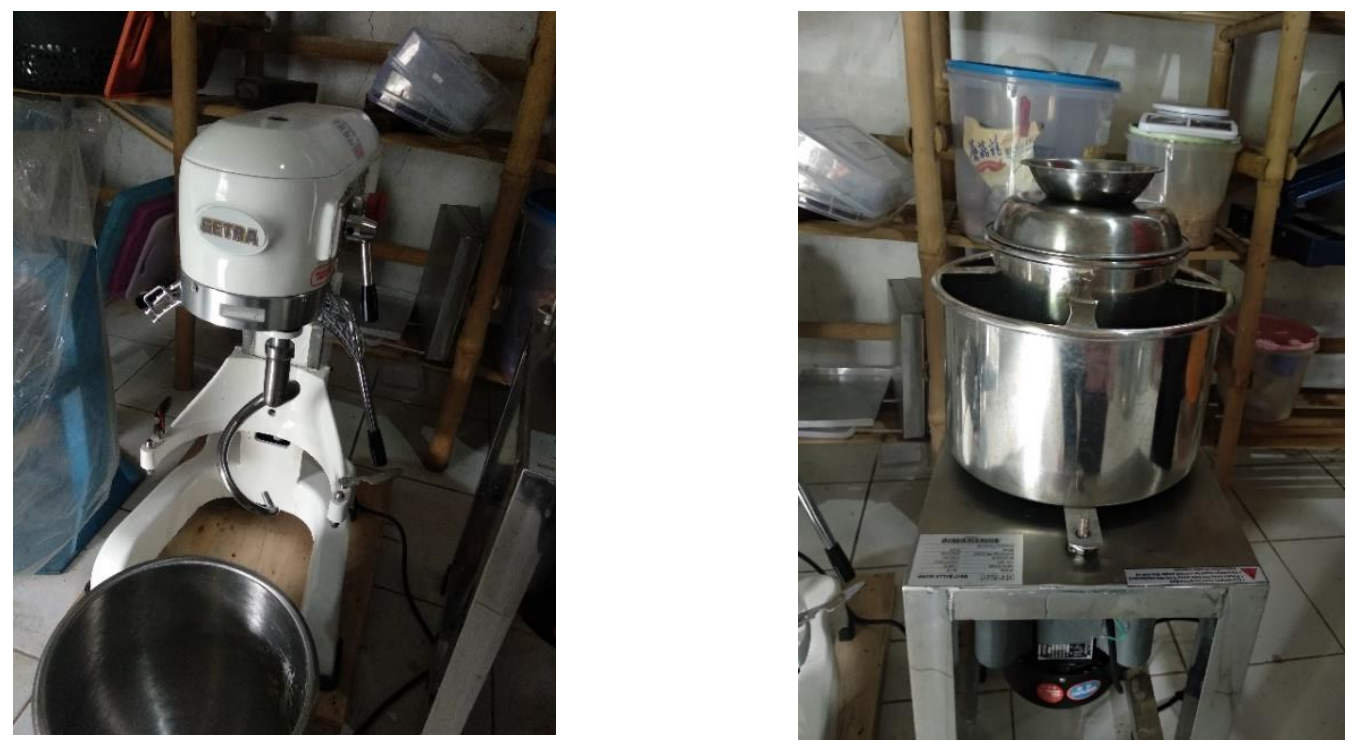

Gambar 2. Mesin Produksi yang Dibeli

Ketika mesin telah tiba, proses produksi pun dimulai dengan melakukan penyetelan awal. Setidaknya membutuhkan waktu 2 hari untuk ujicoba mesin sebelum dapat melakukan produksi reguler. 


\section{B. Pembahasan}

Berdasarkan observasi dan penuturan Bapak Riyan, kapasitas produksi saat ini sudah dapat ditingkatkan. Penggunaan mesin pembuat adonan yang dimiliki saat ini dapat difungsikan dengan kemampuan membuat adonan hingga kalis hanya 15 menit untuk 1,9 kilogram adonan. Perbaikan produksi ini mempercepat proses yang dulunya membutuhkan waktu 2 hari, kini hanya 15 menit saja. Dampak positif langsung dari implementasi mesin ini adalah Bapak Riyan saat ini memiliki banyak waktu membantu istrinya dalam mempersiapkan kegiatan produksi lanjutan setelah membuat adonan dan juga meningkatkan variasi produk baru yang dapat dibuat.

Kapasitas produksi dan standardisasi produksi sangat berkaitan erat. Sebelum hadirnya mesin dan teknologi tepat guna, kegiatan produksi menjadi penghambat utama aktivitas usaha Bapak Riyan. Sebelum adanya mesin, untuk membuat satu adonan seberat 1-2 kilogram saja, Bapak Riyan membutuhkan waktu seharian penuh untuk memproses dan menunggu hingga kalis. Tidak jarang, aktivitas membuat adonan yang mengkonsumsi kondisi fisik sangat tinggi juga membuat Bapak Riyan tidak produktif untuk mengerjakan hal lainnya.

Prioritas masalah yang diperbaiki adalah masalah produksi. Bagian ini perlu diselesaikan sebelum pemasaran karena Bapak Riyan memiliki masalah dengan kapasitas produksi dan standardisasi kualitas. Jika kapasitas produksi belum dapat diselesaikan, maka pesanan sebanyak apapun tidak akan pernah mampu dipenuhi dan pada akhirnya akan mengecewakan konsumen.

Selain kapasitas produksi, masalah standardisasi kualitas menjadi penting agar rasa maupun performa produk milik Bapak Riyan dapat selalu stabil. Hal ini sangat penting sebagai salah satu syarat agar produk Bapak Riyan memiliki daya saing dibandingkan produk-produk usaha lainnya. Teknik dasar ini sangat membantu dalam menyelesaikan masalah kapasitas dan standardisasi produksi yang dialami oleh LeBon. Adapun, untuk mendukung kegiatan tersebut, peneliti juga telah menyusun luaran yang berfungsi sebagai pengingat dari mekanisme standar operasional dari kegiatan produksi di LeBon. Beberapa informasi yang diberikan antara lain:

- Tersedianya poster SIPOC

- Tersedianya Buku SOP Kegiatan Produksi

- Tersedianya manual cara operasi mesin

- Tersedianya poster yang berisi standar kualitas produk yang diterima

Ketersediaan poster SIPOC, buku SOP, manual, maupun poster standar kualitas berguna agar Pak Riyan dapat fokus kepada hal yang lebih stratejik sehingga jika nanti akan merekrut pegawai, terdapat suatu sistem yang memastikan bahwa kualitas dan standar produk akan tetap terjamin.

Akan tetapi, dalam proses pendampingan dalam kegiatan pengabdian masyarakat ini terdapat efek samping yang diluar dugaan awal. Berkat adanya mekanisasi, kini proses produksi menjadi lebih efisien dan efektif. Borosnya waktu membuat adonan yang dulu mencapai dua hari, kini dapat diselesaikan dalam waktu 15 menit saja. Hal ini berakibat ketersediaan waktu menjadi berlimpah karena strategi pemasaran masih disesuaikan dengan situasi saat produksi dengan sistem manual. Oleh karena itu, melalui diskusi intensif dengan Bapak Riyan, diputuskan untuk membuat produk baru masih dengan berbasis ikan, namun dapat memanfaatkan mesin produksi yang ada.

Kemudian, Bapak Riyan mengambil inisiatif untuk mencari produk ikan air laut yang telah diproses dan digiling sehingga lebih mudah dalam proses produksinya. Bapak Riyan memperoleh pasokan daging ikan beku ini dari Pasar Tangerang dengan kualitas produk AA. 
Dalam sekali pembelian, Bapak Riyan menghabiskan 20 kilo bahan dengan biaya hampir Rp 800.000. Sekali pengambilan ini dapat diproses untuk dua sampai tiga minggu produksi.

Melalui strategi diversifikasi produk ini, masalah standardisasi produk dan juga penyusutan bahan baku utama dapat diatasi. Pada masalah standardisasi, keberadaan mesin sudah mendukung pencampuran bumbu merata, sedangkan pada masalah penyusutan daging lele, saat ini dengan penggunaan daging ikan beku, masalah menjadi terselesaikan. Melalui inovasi ini, kini Bapak Riyan dan usaha Le-Bonnya memiliki beragam inovasi produk baru, antara lain:

- Bakso tahu ikan (beku dan siap saji)

- Hagatori

- Fish Tortilla

- Kaki Naga dan berbagai olahan nugget

- Bakso Udang

- Dimsum Udang

\section{Simpulan}

Permasalahan dalam dunia usaha mikro dan kecil sangatlah beragam. Namun, tidak semua masalah harus diselesaikan dengan pendekatan yang rumit dan ilmu yang mutakhir. Permasalahan yang dihadapi oleh Usaha LeBon dalam artikel ini merupakan permasalahan tradisional yang juga dihadapi oleh berbagai macam pengusaha mikro lainnya. Ketiadaan pendanaan namun adanya kebutuhan pemasaran yang mendesak membuat proses produksi tetap dijalankan secara tradisional walaupun mengorbankan kualitas dan standar produksi. Melalui penelitian tindakan dalam kegiatan pengabdian masyarakat ini ditemukan bahwa proses mekanisasi sederhana dalam proses produksi usaha mikro mampu meningkatkan efisiensi produksi hingga 10 kali lipat, dimana sebelumnya membutuhkan waktu dua hari untuk mempersiapkan adonan, dengan adanya mesin produksi waktu dapat dipangkas hingga 15 menit saja.

Akan tetapi mekanisasi tidak dapat berdiri sendiri. Inovasi dan kreativitas dari pemilik usaha tetap dibutuhkan untuk mengantisipasi adanya lonjakan permintaan maupun perubahan tren pasar yang sangat cepat. Tidak hanya itu, peran perguruan tinggi untuk mengkombinasikan penelitian dan pengabdian masyarakat menjadi model yang menarik untuk dapat membantu penyelesaian masalah usaha mikro secara lebih lugas melalui transfer pengetahuan.

\section{Ucapan Terima Kasih}

Pelaksanaan kegiatan pengabdian kepada masyarakat ini dapat terlaksana berkat dukungan dana hibah dari PKM Dikti tahun 2017 dan pendanaan dari Sekolah Bisnis dan Ekonomi Universitas Prasetiya Mulya. Seluruh persyaratan wajib pemenuhan jurnal telah terlaksana dan laporan ini merupakan informasi berharga yang dapat menjadi panduan untuk pengembangan kegiatan hibah selanjutnya.

\section{Daftar Pustaka}

Abrahamsen, M. H., Henneberg, S. C., Huemer, L., \& Naudé, P. (2016). Network picturing: An action research study of strategizing in business networks. Industrial Marketing Management, 59, 107-119. https://doi.org/10.1016/j.indmarman.2016.02.006 
Chang, W.L., Liu, W.G.H., dan Chiang, S. . (2014). A Study of the Relationship between Entrepreneurship Courses and Opportunity Identification: An Empirical Survey. Asia Pacific Management Review, ISSN(19 (1)), 1-24.

Ehrenhard, M., Wijnhoven, F., Broek, T. Van Den, \& Zinck, M. (2017). Technological Forecasting \& Social Change Unlocking how start-ups create business value with mobile applications : Development of an App-enabled Business Innovation Cycle. Technological $\begin{array}{lllll}\text { Forecasting } \& \text { Social } & \text { Change, }\end{array}$ https://doi.org/10.1016/j.techfore.2016.09.011

Hsieh, R., Kelley, D. J., \& Liu, C. (2009). Recognizing Innovative Opportunities: The Mediating Role of Entrepreneurial Alertness. ICSB World Conference Proceedings; , 113. https://search.proquest.com/docview/192410733?accountid=26469

Kusmulyono, M. S. (2016). Peran Pengetahuan Pendahulu Dan Kepekaan Terhadap Kemampuan Mengidentifikasi Peluang Usaha Mikro Pedesaan. Jurnal Manajemen Maranatha, 16(1), 27-42. https://doi.org/10.28932/jmm.v16i1.4

Laage-hellman, J., Landqvist, M., \& Lind, F. (2018). Business creation in networks : How a technology-based start-up collaborates with customers in product development. Industrial Marketing Management, 70(June 2017), 13-24. https://doi.org/10.1016/j.indmarman.2017.07.009

Porter, M. E. (1990). The Competitive Advantage of Nations. The Free Press.

Rahman, H., \& Ramos, I. (2010). Open innovation in SMEs: From closed peripheries to networked paradigm. Issues in Informing Science and Information Technology, 7, 378393. https://doi.org/10.4018/978-1-61692-880-3.ch022

Siegel, D. S., \& Renko, M. (2012). The role of market and technological knowledge in recognizing entrepreneurial opportunities. Management Decision, 50(5), 797-816. https://doi.org/10.1108/00251741211227500

Venkataraman, S. (2000). Shane and Venkataraman 2000. Academy Ol Management Review, $25(1), 217-226$. 